\title{
Transparency and public accessibility of clinical trial information in Croatia: how it affects patient participation in clinical trials
}

\author{
Ivana Šolić ${ }^{1}$, Ana Stipčić2 ${ }^{2}$ Ivančica Pavličević3 ${ }^{3}$ Ana Marušič ${ }^{* 4,5}$ \\ ${ }^{1}$ Medical student, University of Split School of Medicine, Split, Croatia \\ ${ }^{2}$ Department of Health Studies, University of Split, Split, Croatia \\ ${ }^{3}$ Department of Family Medicine, University of Split School of Medicine, Split, Croatia \\ ${ }^{4}$ Department of Research in Biomedicine and Health, University of Split School of Medicine, Split, Croatia \\ ${ }^{5}$ Cochrane Croatia \\ ${ }^{*}$ Corresponding author: ana.marusic@mefst.hr
}

\begin{abstract}
Introduction: Despite increased visibility of clinical trials through international trial registries, patients often remain uninformed of their existence, especially if they do not have access to adequate information about clinical research, including the language of the information. The aim of this study was to describe the context for transparency of clinical trials in Croatia in relation to countries in Central and Eastern Europe, and to assess how informed Croatian patients are about clinical trials and their accessibility.

Materials and methods: We assessed the transparency of clinical trials from the data available in the public domain. We also conducted an anonymous survey on a convenience sample of 257 patients visiting two family medicine offices or an oncology department in south Croatia, and members of national patients' associations.

Results: Despite legal provisions for transparency of clinical trials in Croatia, they are still not sufficiently visible in the public domain. Among countries from Central and Eastern Europe, Croatia has the fewest number of registered trials in the EU Clinical Trials Registry. $66 \%$ of the patients in the survey were aware of the existence of clinical trials but only $15 \%$ were informed about possibilities of participating in a trial. Although $58 \%$ of the respondents were willing to try new treatments, only $6 \%$ actually participated in a clinical trial. 0 nly $2 \%$ of the respondents were aware of publicly available trial registries.

Conclusions: Our study demonstrates that there is low transparency of clinical trials in Croatia, and that Croatian patients are not fully aware of clinical trials and the possibilities of participating in them, despite reported availability of Internet resources and good communication with their physicians. There is a need for active policy measures to increase the awareness of and access to clinical trials to patients in Croatia, particularly in their own language.
\end{abstract}

Key words: access to information; awareness; patient participation; clinical trials; registries

Accepted: May 11, 2017

\section{Introduction}

Transparency is at the heart of health research (1). Transparency and completeness of clinical trial reporting is important not only for unbiased assessment of health interventions and formulation of health practice guidelines, but is also an obligation towards altruistic individuals who volunteer for research $(2,3)$. The increase in the transparency standards for clinical trials that we witness today, from the availability of information about the existence of trials to the availability of trial results and data, is the outcome of joined effort of journal editors, researchers and policy makers to improve the quality of health research and empower the patients and their families to get the best treatment available (3-6). 
Despite the increased openness of information of clinical trials, it is still often difficult to successfully enrol participants into trials. Although most patients seem to be aware and willing to participate in clinical trials, only a small fraction of patients who meet the requirements actually participate in trials $(7,8)$. Only $27 \%$ of patients discuss clinical trials as an option with their physician (9). There is also evidence of gender imbalance in the awareness about clinical trials, with male patients reporting more often that they are informed about clinical trials (10).

One of the main reasons why patients take part in clinical trials is the possibility to benefit from a new treatment $(3,11)$. On the other hand, there are many potential reasons why patients avoid entering a clinical trial. These include the fear of being a "human guinea pig", trying something no one knows whether it would work, worries that they will be in the control group receiving a placebo and be thus left without help, as well as the feeling that joining a clinical trial means that all hope is lost (12). One of the problems contributing to this distrust is the lack of understanding of the methodology of clinical trials and their purpose, despite the information received during informed consent procedure (11). More active engagement in information translation to patients may be beneficial, as studies show that engagement of special educators, who spend more time talking face to face with participants, improve participants' understanding of specific clinical trial (13). Also, new forms of recruitment strategies may bring down some barriers to patient participation in clinical trial (14). However, there is also evidence that education interventions related to participation in clinical trials may not influence the patients' motivation for trial accrual (15).

Patients' knowledge and awareness of and participation in clinical trials may be a special problem for smaller research communities such as Croatia. There is little information on how well patients are informed about clinical trials in Croatia (16). Judging from the experience of low awareness of and adherence to common medical procedures among Croatian patients $(17,18)$, high level of information about participation in clinical trials cannot be expected. One of the reasons for the lack of information on clinical trials in Croatia could be because the information is not available in the Croatian language. Most of the information about clinical trials is available only in English, although some countries have followed the recommendations of the World Health Organization (WHO) and established their national registries of clinical trials, with information available in the native language (19).

The aim of our study was to examine the transparency of official information available about clinical trials conducted in Croatia in comparison to other countries in Central and East Europe, and to explore the awareness and opinions of Croatian patients about clinical trials. We targeted general patient population attending family medicine practices as well as patient groups with special interest in clinical trials - cancer patients and patients' associations.

\section{Materials and methods}

\section{Study design}

\section{Data sources}

To identify the availability of information on clinical trials in Croatia, we searched the web-sites of the Ministry of Health (https://zdravlje.gov.hr/), which is a regulatory competent authority for the approval of clinical trials, and the Agency for Medicinal Products and Medical Devices (http://www. halmed.hr/en/O-HALMED-u/), which hosts the national Central Ethics Committee (CEC). CEC issues opinions in the procedure of granting approvals for clinical trials (20). We compared the legislative framework for the transparency of clinical trials in Croatia to that for other EU countries from Central and Eastern Europe (Bulgaria, Czech Republic, Hungary, Poland, Romania, Slovakia and Slovenia) which had similar social and economic history of transition from socialist to market economy, using the information on the ethics review of clinical trial protocols in Europe collected by the European Forum for Good Clinical Practice $(20,21)$.

The data on the total number of registered clinical trials were collected from two international registers on January 16, 2017: the EU Clinical Trials Reg- 
ister of the European Medicines Agency (https:// www.clinicaltrialsregister.eu/ctr-search/search), which registers interventional clinical trials on medicines conducted in the European Union (EU) and the European Economic Area (EEA) since 2004, and ClinicalTrials.gov (https://clinicaltrials.gov/ct2/ home), which is a registry and results database of clinical studies and is hosted by the National Library of Medicine.

\section{Patient survey}

The survey was performed on a convenient sample during two months in 2015/2016. Participation was invited from the following patients' populations: 1) patients with chronic diseases visiting two family medicine offices, one in the city of Split and one on the island of Hvar; 2) patients from the Department of Oncology of the University of Split Hospital Centre; 3) members of patients' associations at a national level, via pen-and-paper questionnaire or online social media groups. The survey had a single round of data collection, with no reminders. The survey was voluntary and anonymous, and was approved by the Ethics Committee of University of Split School of Medicine as a part of the research grant "Professionalism in Health Care" funded by the Croatian Science Foundation (Grant No. IP-2014-09-7672). The survey included only adult responders, but they could answer questions for their children.

The survey was constructed as a 20-item questionnaire (Table 1) to collect the following information: patients' basic demographic characteristics; predominant disease/condition and received treatments; relationship with their physician(s); satisfaction with the communication with the physician and the treatment received; interest in their disease and for seeking additional information about it; awareness of clinical trials and participation in them; and willingness to participate in a clinical trial. The questionnaire was piloted with four experts to test its face validity; the pilot resulted in minor language changes but no changes in the questions.

TABLE 1. Survey questionnaire

\begin{tabular}{|c|c|}
\hline 1. & General information: Age (number) ${ }^{*}$ _ \\
\hline 2. & The main disease you are suffering from: \\
\hline 3. & $\begin{array}{l}\text { Are you a member of any patients' association (mark the answer)? If the answer is yes, which one? } \\
\text { NO YES Patients' association: }\end{array}$ \\
\hline 4. & $\begin{array}{l}\text { City where you are seeing the specialist physician who treats you from your main disease (you can mark multiple } \\
\text { answers): } \\
\text { a) Zagreb } \\
\text { b) Split } \\
\text { c) Rijeka } \\
\text { d) Osijek } \\
\text { e) Other (which one): }\end{array}$ \\
\hline 5. & $\begin{array}{l}\text { Type of institution where you are getting your treatment (you can mark multiple answers): } \\
\text { University hospital centre } \\
\text { a) Hospital } \\
\text { b) Health centre } \\
\text { c) Family medicine offices } \\
\text { d) Private specialist physician } \\
\text { e) Other (what type): }\end{array}$ \\
\hline 6. & $\begin{array}{l}\text { How often do you see your specialist physician who treats you from your main disease (the average number of visits } \\
\text { per year)? }\end{array}$ \\
\hline 7. & $\begin{array}{l}\text { Does your specialist physician discuss your therapy with you? } \\
\text { No Yes Yes, but not clearly } \\
\text { If you are not satisfied with communication with your physician, please describe a problem: }\end{array}$ \\
\hline
\end{tabular}




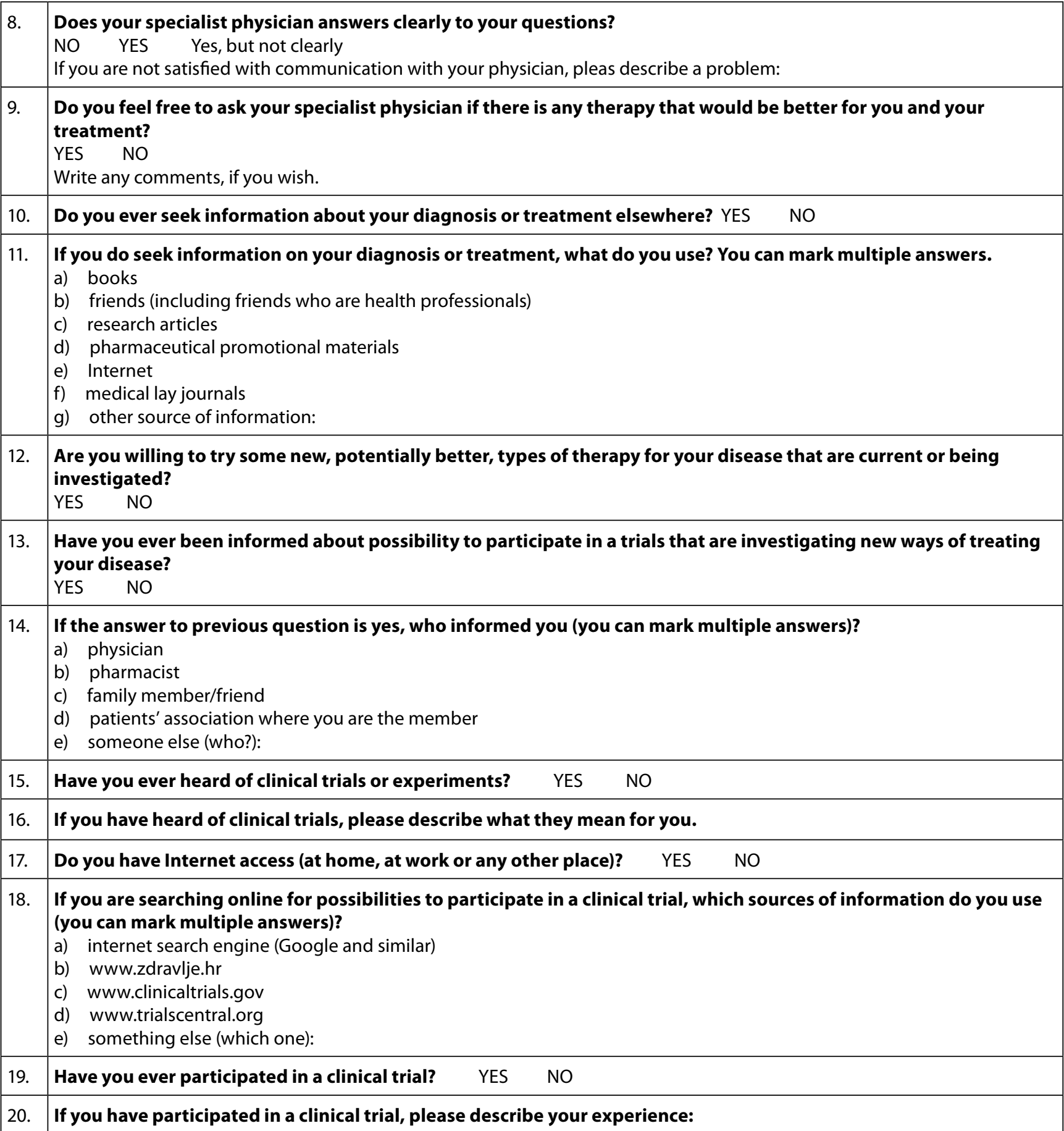

*The online version of the survey had categories for age: $0-17,18-40,41-65,66-80$, and $>80$ years.

\section{Statistical analysis}

Categorical data were presented as percentages or ratios (when $\mathrm{N}<100$ ) and continuous data as median \pm interquartile range. Comparisons were made using chi-square test or Fisher's exact test where expected cell frequency was less than five for categorical data, or Kruskal Wallis test with Mann Whitney $U$ test as a post-hoc test for continuous data. Statistical analysis was performed using 
the SPSS version 18 (SPSS Inc., Chicago, IL). The significance threshold was set at $\mathrm{P}<0.05$ (for posthoc tests, Bonferroni adjustment was made and significance threshold was set at $P<0.01$ ).

\section{Results}

\section{Context for trial registration in Croatia}

The conduct of clinical trials in Croatia is governed by several laws and regulations (20). Clinical trials, both industry and non-industry sponsored, on drugs and medical devices must be approved by the Minister of Health, after positive approval from the national CEC. Trials involving other interventions, which are outside of the scope of the CEC, must be approved by relevant local ethics committees. There is no national policy on the registration of clinical trials before their inception, but there is legal requirement for a register of all approved clinical trials since 2010 (20). However, the scope of this register is not yet defined and it has not been established, as judged by the information from the web-site of the Ministry (January 2017).

The most recent legal regulation requires that all approved trials should be available not only at the web-site of the Ministry of Health but also in the EU Clinical Trial Register (22). The documentation on approved clinical trials from 2010 onward is available in the form of PDF documents at the Ministry's web-site (23). The information on a trial consists of the official scientific title of the trial in English and Croatian, EU register (EUdraCT) number, name of the tested drug, indication (disease), and trial sites (the name of the institution). The documents list 50 trials in 2016, 59 in 2015, 55 in 2014, 77 in 2013 and 57 in 2012. The lists seem to have been updated, as some of the trial from earlier years have a notification that they had been closed. According to the database from the European Forum for Good Clinical Practice from 2012 (20), no information is available on the transparency of clinical trials in Bulgaria, Slovakia and Slovenia, while Romania had no policy on the registration of clinical trials. Hungary had no national policy on trial registration but required that all trials are registered in the EU clinical trial register, EudraCT. Poland has a national register, which is not open to the public but permission may be given to interested persons. The Czech Republic has an open national register.

In order to assess the number of past and currently ongoing trials in Croatia and EU countries in Central and Eastern Europe, we searched the EU Clinical Trial Register (EUCTR) and the ClinicalTrials.gov register (Table 2). At the time of the search (16 January 2017), EU Clinical Trials Register had 29502 clinical trials with a EudraCT protocol conducted in

TABLE 2. Clinical trials from EU countries in Eastern and Central Europe registered in international trial registries*

\begin{tabular}{|c|c|c|c|c|c|c|}
\hline \multirow[b]{2}{*}{ Country } & \multicolumn{3}{|c|}{ EU Clinical Trials Register } & \multicolumn{3}{|c|}{ ClinicalTrials.gov } \\
\hline & Total & Opened (\%) ${ }^{\dagger}$ & $\begin{array}{l}\text { With registered } \\
\text { results (\%) }\end{array}$ & Total & Opened $(\%)^{\dagger}$ & $\begin{array}{l}\text { With registered } \\
\text { results (\%) }\end{array}$ \\
\hline Bulgaria & 1289 & $868(67)$ & $610(47)$ & 1430 & $240(17)$ & $424(30)$ \\
\hline Croatia & 196 & $174(89)$ & $26(13)$ & 772 & $130(17)$ & $225(29)$ \\
\hline Czech Rep. & 3340 & $2421(72)$ & $1606(48)$ & 3304 & $545(16)$ & $969(29)$ \\
\hline Hungary & 3414 & $2473(72)$ & $1612(47)$ & 3028 & $506(17)$ & $929(31)$ \\
\hline Poland & 1771 & $1258(71)$ & $630(36)$ & 4794 & $766(16)$ & $1367(29)$ \\
\hline Romania & 195 & $168(86)$ & $70(36)$ & 1969 & $294(15)$ & $681(35)$ \\
\hline Slovakia & 885 & $625(71)$ & $398(45)$ & 1362 & $167(12)$ & 495 (36) \\
\hline Slovenia & 293 & $223(76)$ & $137(47)$ & 482 & $84(17)$ & $101(21)$ \\
\hline
\end{tabular}

${ }^{*}$ Search performed on 16 January 2017.

†EU Clinical Trials Register: filtered as "Ongoing" for Trial Status in Advanced Search; ClinicalTrials.gov: filtered as "Open Studies" for Recruitment in Advanced Search. 
the European Union (EU) or the European Economic Area (EEA) after 1 May 2004. ClinicalTrials. gov listed 234,467 studies with locations in the USA and 195 other countries. In comparison to other EU countries from Central and Eastern Europe, which joined the EU in 2004 or 2007, Croatia, which joined in 2013, has a smaller number of registered clinical trials in EUCTR (Table 2). Although the percentage of ongoing registered studies was similar in all countries from our comparison (around 70\% or over), the percentage of trials with registered results was the smallest in Croatia: $13 \%$ compared to $36-48 \%$ in other countries (Table 2 ). The content analysis of 26 trials with results posted for Croatia demonstrated that 20 had information only in English, and six had only the scientific title of the trial translated into Croatian, and all other information in English only. In the ClinicalTrials. gov, the percentages of open studies or those with registered results were similar across all countries, with $12-17 \%$ of studies still recruiting and with $21-$ $36 \%$ of trials having registered results.

\section{Patients'survey}

During the sampling time-frame, responses from 257 participants were collected (Table 3 ). We could not calculate the response rate due to the open nature of the survey, including open call to patients via their respective social media groups. There were 117 men (46\%) and 137 women (53\%), mostly in the 41 - 80 age group (67\%). Patients were treated for their major chronic disease or cancer in Split (69\%), Zagreb (25\%) or Osijek (2\%). The treatment was mostly received in university hospital centres (67\%) and in family medicine practices (40\%). Patients reported different chronic conditions and most common diagnosis were carcinomas (26\%), diabetes (13\%) and mental illnesses (12\%). Members of patients' associations constituted $21 \%$ of the respondents.

Although $82 \%$ participants reported that they felt free to ask their physicians about their treatment, $69 \%$ of those were actually interested in asking their physician and/or did ask (Table 4). Even when they asked, $20 \%$ did not understand or did not fully understand the information they got from their physician. Although patients reported good com- munication with their physicians, a half of the respondents searched for more information, mostly from friends (33\%) or the Internet (41\%), predominantly using general searches rather than specialized health sites. Only $2 \%$ of the respondents were

TABLE 3. Descriptive statistics of the study sample

\begin{tabular}{lc}
\hline Characteristics & $\mathbf{N}(\%)^{*}$ \\
\hline Gender & $137(53)$ \\
Female & \\
\hline Age group in years ${ }^{\dagger}:$ & $10(4)$ \\
$0-17$ & $49(19)$ \\
$18-40$ & $92(36)$ \\
$41-65$ & $81(32)$ \\
$66-80$ & $9(4)$ \\
$\geq 81$ &
\end{tabular}

Main disease ${ }^{\ddagger}$ :

$\begin{array}{lc}\text { Cancer/tumour } & 66(26) \\ \text { Mental illness } & 31(12) \\ \text { Diabetes } & 33(13) \\ \text { Hypertension } & 18(7) \\ \text { Heart conditions } & 16(6) \\ \text { Pulmonary diseases } & 7(3) \\ \text { Spine and bones diseases } & 16(6) \\ \text { Other diseases } & 46(18) \\ \text { Patients' association membership } & 53(21)\end{array}$

\section{Place of treatment:}

Zagreb

$64(25)$

Split

177 (69)

Osijek

$6(2)$

\begin{tabular}{lc}
\hline Institution of treatment $^{\ddagger}$ : & \\
University Hospital Centre & $173(67)$ \\
Hospital & $36(14)$ \\
Health centre & $12(5)$ \\
Family medicine offices & $103(40)$ \\
Private specialist physician & $22(9)$
\end{tabular}

${ }^{*}$ Percentages are to the total sample $(\mathrm{N}=257)$, to indicate missing responses.

${ }^{\dagger}$ Children were not recruited for the study, but parents could answer the survey about the experiences in the treatment of their children.

‡Percentages do not add up because multiple choices were possible. 
TABLE 4. Patient's satisfaction and interest about their disease and treatment*

\begin{tabular}{|c|c|c|c|c|}
\hline & $\begin{array}{c}\text { Total } \\
(\mathrm{N}=\mathbf{2 5 7})\end{array}$ & $\begin{array}{c}\text { Men } \\
(N=117)\end{array}$ & $\begin{array}{l}\text { Women } \\
(N=137)\end{array}$ & $\mathbf{p}^{+}$ \\
\hline Feels free to ask physician about the treatment $(\mathrm{N}, \%)$ & $211(82)$ & $100(48)$ & $110(52)$ & 0.190 \\
\hline \multicolumn{5}{|l|}{ Discusses therapy with physician (N, \%): } \\
\hline Yes & $177(69)$ & $77(44)$ & $100(57)$ & \\
\hline Yes, but nor clearly & $37(14)$ & $18(50)$ & $18(50)$ & 0.519 \\
\hline No & $29(11)$ & $15(54)$ & $13(4)$ & \\
\hline \multicolumn{5}{|l|}{ Physician answers to patient's question $(\mathrm{N}, \%)$ : } \\
\hline Yes & $195(76)$ & $90(46)$ & $105(54)$ & \\
\hline Yes, but nor clearly & $35(14)$ & $13(39)$ & $20(61)$ & 0.414 \\
\hline No & $15(6)$ & $9(60)$ & $6(40)$ & \\
\hline $\begin{array}{l}\text { Seeks for information about disease and treatment } \\
\text { elsewhere }\end{array}$ & $133(52)$ & $60(46)$ & $71(54)$ & 0.538 \\
\hline \multicolumn{5}{|c|}{ Source of information seeked elsewhere (multiple responses allowed) (N, \%): } \\
\hline In books & $53(21)$ & $22(42)$ & $30(58)$ & 0.147 \\
\hline Friends (including friends who are health professionals) & $84(33)$ & $39(48)$ & $43(52)$ & 0.377 \\
\hline Research articles & $36(14)$ & $13(36)$ & $23(64)$ & 0.055 \\
\hline Pharmaceutical promotional materials & $12(5)$ & $4(33)$ & $8(67)$ & $0.372^{\ddagger}$ \\
\hline Online & $105(41)$ & $43(41)$ & $61(59)$ & 0.010 \\
\hline Medical lay journals & $19(7)$ & $6(32)$ & $13(68)$ & 0.080 \\
\hline \multicolumn{5}{|l|}{ Online searching tools used $(\mathrm{N}, \%)$ : } \\
\hline Internet search engine (Google or similar) & $107(42)$ & $44(42)$ & $62(59)$ & 0.251 \\
\hline www.zdravlje.hr & $24(9)$ & $12(50)$ & $12(50)$ & 0.317 \\
\hline www.clinicaltrials.gov & $6(2)$ & $1(17)$ & $5(83)$ & $0.232^{\ddagger}$ \\
\hline
\end{tabular}

*The numbers for men and women do not always add because of missing data. The numbers in brackets for man and women are row percentages, and numbers in brackets for the Total are the percentage of all respondents.

${ }^{\dagger}$ Chi-square test. ${ }^{\ddagger}$ Fisher's exact test. $\mathrm{P}<0.05$ was considered statistically significant.

aware of publicly available trial registries, such as ClinicalTrials.gov.

Although $66 \%$ of the respondents were aware of clinical trials, only $15 \%$ were informed about possibilities of participating in a trial (Table 5). Furthermore, $58 \%$ of the respondents were willing to try new treatments but only $6 \%$ actually participated in a clinical trial. Men significantly more often reported being informed about clinical trials than women (63\% vs. $37 \%, P=0.017$ ).

Survey respondents coming from different patients' groups significantly differed in their answers (Table 6). As expected, patients attending the hospital oncology department reported having significantly more annual appointments with the physician(s) than other respondent groups $(\mathrm{P}<$ 0.001 ). Respondents from the online survey and those from patients' associations reported more often that they were aware of clinical trials in comparison to other groups $(P<0.001)$. Online survey respondents also more often reported the willingness to try new treatments that the other groups, except the respondents from patients' organizations $(P=0.014)$.

\section{Discussion}

Our study showed that Croatian patients were not well informed about possibilities of participating in a clinical trial. Although they were reportedly 
TABLE 5. Patient's awareness of clinical trials*

\begin{tabular}{|c|c|c|c|c|}
\hline & $\begin{array}{c}\text { Total } \\
(\mathbf{N}=\mathbf{2 5 7})\end{array}$ & $\begin{array}{c}\text { Men } \\
(\mathrm{N}=117)\end{array}$ & $\begin{array}{c}\text { Women } \\
(N=137)\end{array}$ & $\mathbf{P}^{\dagger}$ \\
\hline Aware of clinical trials $(\mathrm{N}, \%)$ & $169(66)$ & $80(48)$ & $88(52)$ & 0.425 \\
\hline $\begin{array}{l}\text { Informed about possible participation in clinical trials } \\
(\mathrm{N}, \%)\end{array}$ & $38(15)$ & $24(63)$ & $14(37)$ & 0.017 \\
\hline \multicolumn{5}{|c|}{ Informed about possible participation in clinical trials by $(\mathrm{N}, \%)$ : } \\
\hline Physician & $31(12)$ & $20(65)$ & $11(36)$ & 0.316 \\
\hline Pharmacist & $6(2)$ & $3(50)$ & $3(50)$ & $0.669^{\ddagger}$ \\
\hline Family member/friend & $10(4)$ & $4(40)$ & $6(60)$ & $0.156^{\ddagger}$ \\
\hline Patients' association & $6(2)$ & $5(83)$ & $1(17)$ & $0.378^{\ddagger}$ \\
\hline Willingness to try new treatments $(\mathrm{N}, \%)$ & $149(58)$ & $74(50)$ & $74(50)$ & 0.147 \\
\hline Participated in clinical trials $(\mathrm{N}, \%)$ & $15(6)$ & $8(53)$ & $7(47)$ & 0.338 \\
\hline
\end{tabular}

*The numbers for men and women do not always add because of missing data. The numbers in brackets for man and women are row percentages, and numbers in brackets for the Total are percentage of all respondents.

${ }^{\dagger}$ Chi-square test. ${ }^{\ddagger}$ Fisher's exact test. $\mathrm{P}<0.05$ was considered statistically significant.

TABLE 6. Patients' responses according to the place of survey*

\begin{tabular}{|c|c|c|c|c|c|c|}
\hline & $\begin{array}{c}\text { City family } \\
\text { medicine office } \\
(\mathbf{N}=87)\end{array}$ & $\begin{array}{l}\text { Island family } \\
\text { medicine office } \\
(\mathbf{N}=\mathbf{3 1})\end{array}$ & $\begin{array}{l}\text { Hospital oncology } \\
\text { department } \\
(\mathrm{N}=52)\end{array}$ & $\begin{array}{l}\text { Patients' } \\
\text { associations } \\
(\mathbf{N}=\mathbf{5 5})\end{array}$ & $\begin{array}{l}\text { On-line patient } \\
\text { survey } \\
(\mathbf{N}=32)\end{array}$ & $\mathbf{P}^{\dagger}$ \\
\hline \multicolumn{7}{|l|}{ Gender (N) } \\
\hline Male & 42 / 87 & $14 / 30$ & $22 / 52$ & $23 / 55$ & $16 / 30$ & \multirow{2}{*}{0.825} \\
\hline Female & 45 / 87 & $16 / 30$ & $30 / 52$ & $32 / 55$ & $14 / 30$ & \\
\hline $\begin{array}{l}\text { No. of appointments } \\
\text { with physician per } \\
\text { year (median, IQR) }\end{array}$ & $2(3)$ & $2(2)$ & $14(20)$ & $3(3)$ & $4(3)$ & $<0.001^{\ddagger}$ \\
\hline $\begin{array}{l}\text { Seeks for information } \\
\text { about disease and } \\
\text { treatment elsewhere (N) }\end{array}$ & 38 / 81 & $19 / 31$ & $26 / 51$ & $30 / 54$ & $20 / 29$ & 0.272 \\
\hline $\begin{array}{l}\text { Willingness to try new } \\
\text { treatments (N) }\end{array}$ & $46 / 79$ & $13 / 29$ & $32 / 46$ & $33 / 55$ & $25 / 29$ & $0.014^{\S}$ \\
\hline $\begin{array}{l}\text { Awareness of clinical } \\
\text { trials (N) }\end{array}$ & 43 / 85 & $17 / 30$ & $35 / 48$ & $46 / 53$ & $28 / 29$ & $<0.001^{\#}$ \\
\hline $\begin{array}{l}\text { Informed about } \\
\text { possible participation } \\
\text { in clinical trials }(\mathrm{N})\end{array}$ & $13 / 81$ & $3 / 29$ & $7 / 50$ & $12 / 54$ & $3 / 29$ & 0.598 \\
\hline $\begin{array}{l}\text { Participated in clinical } \\
\text { trials (N) }\end{array}$ & $5 / 82$ & $1 / 31$ & $0 / 50$ & $7 / 53$ & $2 / 29$ & 0.060 \\
\hline
\end{tabular}

*Data as presented as the number of responses/total responses for the question.

${ }^{\dagger}$ Chi-square test or Fisher's exact test for comparisons including cell frequencies less than five. Bonferroni adjustment for all post hoc analysis was set to the significance threshold of $P=0.01$. ${ }^{\ddagger}$ Kruskal-Wallis test and post-hoc analysis (Mann Whitney $U$ test): Hospital oncology department group vs all other survey places $(P<0.001)$. ${ }^{\S}$ Post-hoc analysis: Online-patient survey group vs Island family practice group $(P=0.001)$, City family medicine office group $(P=0.007)$ and Patients' association group $(P=0.014)$. \#Post-hoc analysis: City family medicine office group vs Patients' association group $(P<0.001)$; Hospital oncology department group $(P=$ 0.012 ) and On-line patient survey group $(P<0.001)$; Island family medicine office vs Patients' association group $(P=0.002)$ and On-line patient survey group $(P<0.001)$; Hospital oncology department group vs On-line patient survey group $(P=0.009)$. 
aware of existence of trials, they did not take the opportunity to participate in them. Only $12 \%$ of the patients reported to be informed about clinical trials by their physicians, which is much lower than current percentages reported elsewhere in EU, such as $27 \%$ in England and Scotland (9). Men in our study, similar to the study in the UK more often reported knowledge of clinical trials, although women significantly more often used the Internet to search for health information, as has been shown for other patient populations $(9,24)$.

The results of our survey should be interpreted with caution because of the methodological constraints of the convenient survey sample and selfreported nature of the answers. The survey was performed in a single university hospital centre and two family medicine practices in south Croatia, as well as on a national, albeit small sample of members from patients' organizations, and cannot be fully representative of the whole Croatia. The sample may have been biased towards patients treated in larger cities in Croatia, as over 90\% of the respondents were treated in two largest hospital settings - Zagreb and Split. However, this means that the observed low level of engagement in or information on clinical trials in such a sample may be an underestimation of the situation at the national level, and may be even lower in rural areas. Our study is, to the best of our knowledge, the first published survey of patients' awareness and participation in clinical trials in Croatia, and should be taken as the baseline evidence for any future actions and interventions to increase the knowledge and participation in clinical trials.

The low awareness and participation of patients in clinical trials observed in our study may be linked to low transparency of clinical trials in Croatia. Although Croatia has good legal provisions for increasing trial transparency, with the requirement for listing of the approved trials and the national register (22), neither the listing of approved trial nor the register had been fully implemented: the register does not exist and the listings lack sufficient information for someone who may be eligible for a trial. For example, only the institutions where the trial is performed are listed, without contact details for responsible person(s) that could be contacted about trial participation. In contrast, major trial registers, like the ClinicalTrials.gov in the USA, have been developed to help individuals with serious or life-threatening diseases or conditions and their families to find trials testing new interventions, as well as to help researchers identify most suitable participants for the trials (25). The lack of sufficient information on approved trials at the Ministry site is also against the standards of the $\mathrm{WHO}$ in regard to the minimum amount of information needed for trial registration (26): 1) Primary Registry and Trial Identifying Number; 2) Date of Registration in Primary Registry; 3) Secondary Identifying Numbers; 4) Source(s) of Monetary or Material Support; 5) Primary Sponsor; 6) Secondary Sponsor(s); 7) Contact for Public Queries; 8) Contact for Scientific Queries; 9) Public Title; 10) Scientific Title; 11) Countries of Recruitment; 12) Health Condition(s) or Problem(s) Studied; 13) Intervention(s); 14) Key Inclusion and Exclusion Criteria; 15) Study Type; 16) Date of First Enrolment; 17) Target Sample Size; 18) Recruitment Status; 19) Primary Outcome(s) and 20) Key Secondary Outcomes.

According to our analysis of information on trials available in major international registries, Croatian patients can learn most about potentially relevant clinical trial from ClinicalTrials.gov then from any other, including the EUCTR. In general, ClinicalTrials.gov has more registered studies from the countries analysed in our study than the EUCTR, mostly because the scope of the two registers is different and the US register is older than the $\operatorname{EUCTR}(5,6)$. EUCTR, which Croatia officially joined in 2013, still has the fewest number of registered trials from Croatia, especially those with already available results. Unfortunately, almost all of the information in EUCTR is not in Croatian, and all information in the ClinicalTrials.gov is in English.

In conclusion, despite increased transparency of clinical trials worldwide, Croatian patients still have limited access to full information about clinical trials performed in Croatia, particularly in their own language and have low awareness about clinical trials and the possibilities of participating in them is rather low, despite reported availability of Internet resources and good communication with their 
physicians. The first step in increasing this transparency for the benefit of the patients would be to fully implement legal provisions that have existed for more than five years (20). Only when the basic information about clinical trials is full, transparent and easily accessible, preferably in native language, efforts could be focused on managing the communication with patients (14), with physicians and other health workers to support participation in clinical trials and clear insecurities with participants (27).

\section{Acknowledgements}

We thank Dr. Marin Rojnica from Jelsa family medicine practice from the island of Hvar, Prof. Eduard Vrdoljak and the staff of the Department of Oncology, University of Split Hospital Centre, and Cochrane Croatia for their help in conducting the survey. This study was funded by the Croatian Science Foundation, grant No. IP-2014-09-7672 “Professionalism in Health Care". The funder had no role in the design of this study, during its execution and data interpretation.

\section{Potential conflict of interest}

None declared.

\section{References}

1. Šimundić AM. Bias in research. Biochem Med (Zagreb) 2013;23:12-5. https://doi.org/10.11613/BM.2013.003

2. Meerpohl JJ, Schell LK, Bassler D, Gallus S, Kleijnen J, Kulig $M$, et al. OPEN project consortium. Evidence-informed recommendations to reduce dissemination bias in clinical research: conclusions from the OPEN (Overcome failure to Publish $n$ Egative fiNdings) project based on an international consensus meeting. BMJ Open 2015;5:e006666. https://doi. org/10.1136/bmjopen-2014-006666

3. De Angelis C, Drazen JM, Frizelle FA, Haug C, Hoey J, Horton $R$, et al. International Committee of Medical Journal Editors. Clinical trial registration: a statement from the International Committee of Medical Journal Editors. N Engl J Med 2004;351:1250-1. https://doi.org/10.1056/NEJMe048225

4. International Committee of Medical Journal Editors. Sharing clinical trial data: a proposal from the International Committee of Medical Journal Editors. Available at: http:// www.icmje.org/news-and-editorials/M15-2928-PAP.pdf. Accessed April 30th 2017.

5. Zarin DA, Tse T, Williams RJ, Carr S. Trial reporting in ClinicalTrials.gov - The final rule. N Engl J Med 2016;375:19982004. https://doi.org/10.1056/NEJMsr1611785

6. European Medicines Agency. Clinical data publication. Available at: http://www.ema.europa.eu/ema/index.jsp?curl=pages/special_topics/general/general_content_000555.jsp\&mid=WCOb01ac05809f363e. Accessed January 17th 2017.

7. Bazarbashi S, Hassan A, Eldin AM,Soudy H, Hussain F. Awareness and perceptions of clinical trials in cancer patients and their families in Saudi Arabia. J Cancer Educ 2015;30:655-9. https://doi.org/10.1007/s13187-015-0797-0

8. Anderson KM, Olson S, ed. Strategies for ensuring diversity, inclusion, and meaningful participation in clinical trials: Proceedings of a workshop. Washington DC: The National

Academies of Sciences, Engineering, and Medicine, The National Academic Press; 2016. Available at: https://www.nap. edu/catalog/23530/strategies-for-ensuring-diversity-inclusion-and-meaningful-participation-in-clinical-trials. Accessed January 17th 2017.

9. Gray, R. Cancer Research UK [Internet] Cancer care in England and Scotland - what do patients really think? London: Rose Gray. 2006 June 8. Available at: http://scienceblog.cancerresearchuk.org/2016/06/08/cancer-care-in-england-and-scotland-what-do-patients-really-think/. Accessed 12th January 2017.

10. Williams S. Clinical trials recruitment and enrollment: attitudes, barriers, and motivating factors, A Summary of Literature and Market Research Reports Held by National Cancer Institute as of August 2004. Available at: http://cro.rbhs.rutgers.edu/documents/clinical_trials_recruitment_and_enrollment.pdf. Accessed January 17th 2017.

11. Meneguin S, Cesar LA. Motivation and frustration in cardiology trial participation: the patient perspective. Clinics (Sao Paulo) 2012;67:603-8. https://doi.org/10.6061/clinics $/ 2012(06) 10$

12. Quinn GP, Bell BA, Bell MY, Caraway VD, Conforte D, Graci $L B$, et al. The guinea pig syndrome: improving clinical trial participation among thoracic patients. J Thorac Oncol 2007;2:191-6. https://doi.org/10.1097/ JTO.0b013e318031cdb6

13. Flory J, Emanuel E. Interventions to improve research participants' understanding in informed consent for research. JAMA 2004;292:1593-601. https://doi.org/10.1001/ jama.292.13.1593

14. Almutairi KM, Alonazi WB, Alodhayani AA, Vinluan JM, Moussa $M$, Al-Ajlan AS, et al. Barriers to cancer clinical trial participation among Saudi nationals: A cross-sectional study. J Reliq Health 2016 Sept 15 [cited 2017 Jan 17]. [Epub ahead of print]. 
15. Stiles CR, Johnson L, Whyte D, Nergaard TH, Gardner J, Wu J. Does increased patient awareness improve accrual into cancer-related clinical trials? Cancer Nurs 2011;34:E13-9. https://doi.org/10.1097/NCC.0b013e31820254db

16. Dražić $M$, Ivčić S. [Kliničko ispitivanje - priručnik za bolesnike i njihove obitelji. Hrvatski časopis za javno zdravstvo]. 2010; 6. Available at: http://www.hcjz.hr/index.php/hcjz/article/view/807/773. Accessed January 17th 2017. (in Croatian)

17. Miler $M$, Šimundić AM. Low level of adherence to instructions for 24-hour urine collection among hospital outpatients. Biochem Med (Zagreb) 2013;23:316-20. https://doi. org/10.11613/BM.2013.038

18. Kackov S, Simundic AM, Gatti-Drnic A. Are patients well informed about the fasting requirements for laboratory blood testing? Biochem Med (Zagreb) 2013;23:326-31. https://doi. org/10.11613/BM.2013.040

19. World Health Organization. Primary Registries. Available at: http://www.who.int/ictrp/network/primary/en/. Accessed January 11th 2017.

20. European Forum for Good Clinical Practice. EFGCP Report on The Procedure for the Ethical Review of Protocols for Clinical Research Projects in Europe and Beyond. Available at: http://www.efgcp.eu/EFGCPReports.asp?L1=5\&L2=1 Accessed January 16th 2017.

21. Džakula A, Sagan A, Pavić N, Lončarek K, Sekelj-Kauzlarić K. Croatia: health system review. Health Syst Transit 2014;16:1162.
22. Republic of Croatia. [Pravilnik o kliničkim ispitivanjima lijekova i dobroj kliničkoj praksi. National Gazette 2015;25:534. Available at: http://narodne-novine.nn.hr/clanci/sluzbeni/2015_03_25_534.html. Accessed January 16th 2017. (in Croatian)

23. Republic of Croatia, Ministry of Health. [Clinical trials of drugs and medical devices]. Available at: https://zdravlje.gov. hr/o-ministarstvu/djelokrug-1297/lijekovi-i-medicinskiproizvodi-1349/1349. Accessed January 16th 2017. (in Croatian)

24. Bidmon S, Terlutter R. Gender differences in searching for health information on the internet and the virtual patientphysician relationship in Germany: Exploratory results on how men and women differ and why. J Med Internet Res 2015; 17:e156. https://doi.org/10.2196/jmir.4127

25. ClinicalTrials.gov. History, policies and laws. Available at: https://clinicaltrials.gov/ct2/about-site/history. Accessed January 17th 2017.

26. World Health Organization. International Clinical Trials Registry Platform (ICTRP). WHO Dataset. Available at: http:// www.who.int/ictrp/network/trds/en/. Accessed January 17 th 2017.

27. Foster JM, Sawyer SM, Smith L, Reddel HK, Usherwood T. Barriers and facilitators to patient recruitment to a cluster randomized controlled trial in primary care: lessons for future trials. BMC Med Res Methodol 2015;15:18. https://doi. org/10.1186/s12874-015-0012-3 